\title{
BIOCHEMICAL STUDY OF MUSCLE IN PROGRESSIVE MUSCULAR DYSTROPHY ${ }^{1}$
}

\author{
BY JEAN-CLAUDE DREYFUS, GEORGES SCHAPIRA, AND FANNY SCHAPIRA
}

(From the Laboratoire de Recherches de Biochimie Médicale [Service du Professeur Robert Debre], Hôpital des Enfants Malades, Paris, France)

(Submitted for publication May 11, 1953; accepted January 13, 1954)

Current concepts of progressive muscular dystrophy hold that it is a disease in which, through genetic error, there are intrinsic defects in muscle metabolism, although the nature of these hypothetical defects remains unrecognized. It is the purpose of this report to describe one approach to the problem and to show that there are defects in the metabolism of isolated muscle from patients with progressive muscular dystrophy.

\section{METHODS}

Assessment of enzymatic activity of skeletal muscle obtained by biopsy presents several difficulties. In the first place, as in any quantitative chemical analysis of mixed tissues, there is the question of an adequate reference base, as discussed by Hoagland (1) and by other investigators (2). A specimen of muscle obtained by biopsy contains varying proportions of fatty tissue, nonmuscular fibrous tissue, vascular tissue, extracellular water, and muscle fibers. Diseased muscle is particularly variable in its heterogeneity, and it has been important to the present study to estimate the degree of fibrous replacement of muscle in biopsy specimens. The reference base selected was non-collagen nitrogen (2), a term applied to nitrogen content of material soluble in dilute alkali, as distinguished from alkali-insoluble collagen and elastin.

A second difficulty associated with assessment of enzymatic activity results from inter-action of enzyme systems present in the muscle sample. Since purification of enzymes is not yet quantitative, it has been necessary to employ impure preparations as test systems. In multi-enzyme systems, such as the glycolytic series, the over-all rate is limited by a single slowest step. This renders quantitative assessment of any other step uncertain, since the rate of the reaction will be proportional to the quantity of enzyme only if that reaction is rate-limiting. The difficulty has been circumvented in the case of phosphorylase by Cori and Cori (3) by inhibiting the next enzyme in the chain, and in the case of aldolase by Sibley and Lehninger (4) by removing from the system the product of the reaction under study. Because suitable methods for their determination were available, these two enzymes, phosphorylase and aldolase were selected for study.

${ }^{1}$ Supported by grants from the Caisse Nationale de Sécurité Sociale (France), the Institut National d'Hygiène (France), and the Muscular Dystrophy Associations (U. S. A.).
In addition, establishment of non-collagen nitrogen as a reference base provided an opportunity to repeat previous observations on the non-heminic iron content of muscle. Earlier work from this laboratory $(5,6)$ showed that non-heminic iron (that is, iron not included in chromoproteins, myoglobin, and the cytochromes) occurred in muscle in two varieties; one extractable by reducing agents, the second apparently linked with myosin (7). It had been found that the extractable iron in muscle from dystrophic patients was low in terms either of wet weight of muscle or of fat-free dry weight (8-10).

Biopsies of muscle were obtained under general anesthesia. The samples were frozen at once in liquid nitrogen and analyses were performed without delay. Biopsies from patients without muscular dystrophy, controls, were obtained from the right transversus abdominis during operation for appendicitis. Biopsies from patients with muscular dystrophy were obtained from the left transversus abdominis. After freezing the muscle, an aqueous extract was prepared in the Potter-Elvehjem homogenizer held at the temperature of melting ice. The extracting medium was 20 volumes of $0.1 \mathrm{~N}$ sodium fluoride. Aliquots were analyzed for non-collagen nitrogen (11), for total nitrogen, for aldolase concurrently by the method of Dounce, Beyer, and Barnett $(12,13)$ and by the method of Sibley and Lehninger (4), and for phosphorylase by the Coris' method (3). In addition, in a number of patients the activity of aldolase in serum was also assessed (14). In three patients interpretation of values for non-collagen nitrogen were checked by determination of collagen and elastin (scleroproteins) by the method of Neumann and Logan (15). Extractable iron was determined colorimetrically with orthophenanthroline, using sodium dithionine as a reducing agent (16).

For phosphorylase assay the homogenate was centrifuged, the supernatant extract diluted with two volumes of a mixture of cysteine and $\mathrm{NaF}, \mathrm{pH} 6.0$, and left for two minutes at $38^{\circ}$. One-tenth $\mathrm{ml}$. was used for the assay. Final concentration of cysteine was $0.05 \mathrm{M}, \mathrm{pH}$ 6.0. For aldolase assay the $1 / 20$ extract was diluted with four volumes of water. Two-tenths $\mathrm{ml}$. were used in the presence of $0.5 \mathrm{ml}$. $0.01 \mathrm{M}$ fructose diphosphate, hydrazine and collidine buffer $\mathrm{pH} 7.5$.

\section{RESULTS}

In Table I, collagen nitrogen is expressed as per cent of total nitrogen in the biopsy specimen. There was a definite increase in collagen nitrogen 
BIOCHEMICAL STUDY OF MUSCLE IN MUSCULAR DYSTROPHY

TABLE I

Ratio of collagenous nitrogen to total nitrogen (in per cent)

\begin{tabular}{cc}
\hline \hline Controls & Dystrophics \\
\hline 9.6 & 36 \\
18.5 & 50 \\
15 & 22 \\
10 & 40 \\
16.6 & 16 \\
11 & 52 \\
17 & 26 \\
10 & 45 \\
6 & 22 \\
& 33 \\
& 36 \\
& 50 \\
& 40 \\
& 21 \\
& 38 \\
& 35 \\
& 20 \\
\end{tabular}

Mean :

34.2 per cent \pm 2.6

in muscle from patients with muscular dystrophy; the single patient in the high normal range was only slightly affected clinically. In general, the relative collagen nitrogen content was higher in those in whom the disease seemed most advanced, although it never exceeded half the total nitrogen even when enzymatic activity had virtually disappeared, as will be presented later.

Determination of collagen and elastin by the method of Neumann and Logan (15) agreed closely with the value obtained by the simpler method. The content of hydroxyproline in collagen, the amino acid upon which the measurement depends, was presumably the same in normal and dystrophic subjects.

These data confirm the well-known increase in fibrous tissue, seen histologically in dystrophic skeletal muscle.

The activity of phosphorylase "a" and " $b$ " was quite reproducible in normal muscle (Tables II and III), phosphorylase " $b$ " being defined as phosphorylase activity in the presence of adenylic acid. In muscle from all but one of the dystrophic patients, phosphorylase activity was reduced greatly, both in terms of wet weight of muscle or of its non-collagen nitrogen content. In both normal and dystrophic muscle, addition of adenylic acid produced an increase of 30 to 40 per cent in phosphorylase activity. Muscle from two patients with severe dystrophy had almost no phosphorylase ac-
TABLE II

Phosphorylase " $a$ "

\begin{tabular}{ccccc}
\hline \hline \multicolumn{2}{c}{$\begin{array}{c}\text { Units per Gm. of } \\
\text { wet muscle }\end{array}$} & & \multicolumn{2}{c}{$\begin{array}{c}\text { Units per Gm. of non- } \\
\text { collagenous proteins }\end{array}$} \\
\cline { 5 - 6 } Controls & Dystrophics & & Controls & Dystrophics \\
\hline 1435 & 325 & & 9570 & 4330 \\
1500 & 80 & & 8810 & 1070 \\
1960 & 483 & & 10800 & 3710 \\
1360 & 430 & & 8710 & 3870 \\
1180 & 1190 & & 6740 & 7580 \\
1140 & 26 & 6910 & 346 \\
& 262 & & & 1820 \\
& 164 & 120 & & 1200 \\
& 385 & 297 & & 4000 \\
& & & &
\end{tabular}

Mean : $1429 \pm 112 \quad 360 \pm 96$

$8590 \pm 630 \quad 2890 \pm 544$

TABLE III

Phosphorylase " $b$ " *

\begin{tabular}{ccccc}
\hline \hline \multicolumn{2}{c}{$\begin{array}{c}\text { Units per Gm. of } \\
\text { wet muscle }\end{array}$} & & \multicolumn{2}{c}{$\begin{array}{c}\text { Units per Gm. of non- } \\
\text { collagenous proteins }\end{array}$} \\
\cline { 2 - 2 } \cline { 5 - 5 } Controls & Dystrophics & & Controls & Dystrophics \\
\hline 1575 & 560 & & 10000 & 7400 \\
2000 & 142 & & 11800 & 1900 \\
3150 & 595 & & 17400 & 4570 \\
2540 & 682 & & 16150 & 6100 \\
1610 & 1700 & & 8000 & 10800 \\
1995 & 70 & & 12000 & 1000 \\
& 638 & & & 4400 \\
& 420 & & & 4000 \\
& 245 & & & 2450 \\
& 470 & & & 3000 \\
& 420 & &
\end{tabular}

Mean: $2145 \pm 226 \quad 540 \pm 127$

$12570 \pm 12254640 \pm 840$

* By agreement, the total phosphorylase activity in the presence of adenylic acid is called "phosphorylase b activity."

tivity, although half the nitrogen in the muscle samples from them was non-collagen nitrogen.

Aldolase activity (Table IV) varied in normal muscle to a somewhat greater extent than did phosphorylase activity. Nevertheless, this variation did not obscure a definite decrease in aldolase activity in dystrophic muscle, which was, on the average, only a third that of normal, referred to non-collagen nitrogen. Again, in several patients, aldolase activity was nearly absent.

These decreases in phosphorylase and in aldolase activity conceivably might have been due to the presence of an inhibitor in dystrophic muscle. This possibility was eliminated by the results of experiments in which the extracts of dystrophic muscle were incubated with crystalline aldolase 
TABLE IV

Aldolase

\begin{tabular}{|c|c|c|c|}
\hline \multicolumn{2}{|c|}{$\begin{array}{l}\text { Units per Gm. of } \\
\text { wet muscle }\end{array}$} & \multicolumn{2}{|c|}{$\begin{array}{l}\text { Units per Gm. of dry non- } \\
\text { collagenous proteins }\end{array}$} \\
\hline Controls & Dystrophics & Controls & Dystrophics \\
\hline $\begin{array}{l}1.576 \\
5.45 \\
4.85 \\
3.4 \\
2.26 \\
2.385 \\
2.68 \\
3.88\end{array}$ & $\begin{array}{l}0.17 \\
0.6 \\
0.745 \\
1.49 \\
0.10 \\
1.45 \\
0.64 \\
0.79 \\
1.085\end{array}$ & $\begin{array}{l}10 \\
32 \\
26.8 \\
21.8 \\
12.8 \\
14.4 \\
18.6 \\
23.9\end{array}$ & $\begin{array}{c}2.26 \\
4.58 \\
6.7 \\
9.4 \\
1.33 \\
10 \\
6 \\
7.9 \\
11.0\end{array}$ \\
\hline
\end{tabular}

Mean: $3.31 \pm 0.47 \quad 0.78 \pm 0.16 \quad 20 \pm 2.75 \quad 6.6 \pm 1.18$

and phosphorylase. No inhibiting effect was noted.

In 36 of 38 patients with muscular dystrophy, aldolase activity of serum was higher than in normal subjects. The mean value was 10 times greater than that of controls. Patients with other neuromuscular disorders and marked wasting of muscle did not show abnormal serum aldolase activity. Details of this study are reported elsewhere (17).

Results of determination of non-heminic iron appear in Table V, with data from earlier studies. Although the iron content was reduced when referred to wet weight of dystrophic muscle, when referred to non-collagen nitrogen, the iron content of dystrophic muscle was exactly the same as that of control muscle. On the contrary, in atrophy of nervous origin, the iron content was increased.

\section{DISCUSSION}

Data reported herein demonstrate a real decrease in the activity of two glycolytic enzymes in skeletal muscle of patients with muscular dystrophy and, confirming the observation on two cases by Sibley and Lehninger (14), an increase in the concentration of one of them, aldolase, in serum. It is too soon to say whether these enzymatic defects are the cause of the dystrophy or whether they are simply

TABLE $\mathbf{v}$

Muscle iron

\begin{tabular}{|c|c|c|c|c|c|c|c|c|c|}
\hline \multirow[b]{2}{*}{ Muscle } & \multicolumn{3}{|c|}{$\begin{array}{l}\text { mg. per } 1000 \mathrm{Gm} \text {. } \\
\text { wet muscle }\end{array}$} & \multicolumn{3}{|c|}{$\begin{array}{l}\text { mg. per } 1000 \mathrm{Gm} \text {. } \\
\text { dry defatted muscle }\end{array}$} & \multicolumn{3}{|c|}{$\begin{array}{l}\text { mg. per } 1000 \mathrm{Gm} \text {. dry } \\
\text { non-collagenous protein }\end{array}$} \\
\hline & Control & $\begin{array}{c}\text { Progressive } \\
\text { muscular } \\
\text { dystrophy }\end{array}$ & Atrophy & Control & $\begin{array}{l}\text { Progressive } \\
\text { muscular } \\
\text { dystrophy }\end{array}$ & Atrophy & Control & $\begin{array}{l}\text { Progressive } \\
\text { muscular } \\
\text { dystrophy }\end{array}$ & Atrophy \\
\hline Transversus & $\begin{array}{l}25.5 \\
18 \\
12 \\
30 \\
17.6\end{array}$ & $\begin{array}{l}10 \\
14.5 \\
18.4 \\
8 \\
15.5 \\
12.6 \\
16.4 \\
8.3\end{array}$ & & $\begin{array}{r}125 \\
75 \\
60 \\
140 \\
85\end{array}$ & $\begin{array}{l}72 \\
72 \\
90 \\
39 \\
77\end{array}$ & & $\begin{array}{r}170 \\
107 \\
66 \\
214 \\
100\end{array}$ & $\begin{array}{r}133 \\
200 \\
140 \\
70 \\
100 \\
87 \\
150 \\
88\end{array}$ & \\
\hline $\begin{array}{l}\text { Gluteus } \\
\text { maximum }\end{array}$ & $\begin{array}{l}18.5 \\
17 \\
13.2 \\
12.9\end{array}$ & $\begin{array}{r}8.5 \\
4 \\
15.3 \\
9.8 \\
10.9 \\
11.5 \\
17.5 \\
11.8 \\
15.6 \\
15.6\end{array}$ & $\begin{array}{l}20.5 \\
30 \\
44 \\
42 \\
32.5 \\
32\end{array}$ & $\begin{array}{r}100 \\
75 \\
68 \\
65\end{array}$ & $\begin{array}{r}50 \\
25 \\
53 \\
110 \\
67 \\
122 \\
66 \\
78 \\
90\end{array}$ & $\begin{array}{l}195 \\
185 \\
280 \\
235 \\
210 \\
170\end{array}$ & . & & . \\
\hline Triceps & & $\begin{array}{c}17 \\
8 \\
7.5 \\
17.5 \\
9.3 \\
12.4 \\
12 \\
8.8 \\
11.7\end{array}$ & $\begin{array}{l}32.5 \\
25 \\
35 \\
28\end{array}$ & & $\begin{array}{c}90 \\
38 \\
37.5 \\
112 \\
67 \\
70 \\
50 \\
63\end{array}$ & $\begin{array}{l}162 \\
135 \\
178\end{array}$ & & . & 280 \\
\hline $\begin{array}{l}\text { Pectoral } \\
\text { major }\end{array}$ & & $\begin{array}{r}9.6 \\
24.5\end{array}$ & & $\begin{array}{r}70 \\
120\end{array}$ & & & & & \\
\hline Mean & 18.1 & 12.2 & 32.15 & 90 & 70 & 195 & 131 & 121 & \\
\hline
\end{tabular}


sequelae of a more primary biochemical flaw. Mirski and Wertheimer (18) Humoller, Hatch and McIntyre (19), other investigators (20) and we (unpublished observations) have demonstrated decreased muscle phosphorylase activity following transsection of the sciatic nerve, and we have observed it also in muscle made atrophic by tenotomy. Fischer (21) similarly described a fall in muscle aldolase activity following sciatic section. In all these cases the decrease in enzyme activity was secondary to the atrophy and was detected by reference to fresh weight of tissue. It may also be noted that decrease in enzyme activity appeared late in these situations when atrophy was wellestablished, although it cannot be implied that the decreases in dystrophic muscle represent an early biochemical lesion.

Nor can it be stated whether or not the decrease in aldolase and phosphorylase activity is unique. It is entirely possible that more widespread disturbance of glycolytic activity, and even of other enzymes may occur in muscular dystrophy.

\section{SUMMARY}

1. Collagen and elastin content of dystrophic muscle was increased.

2. In muscle obtained by biopsy from patients with progressive muscular dystrophy there was a decrease in the activity of phosphorylase and of aldolase. This decrease was demonstrable either when the values were expressed in terms of the wet weight of the sample or in terms of its remaining muscle fibrillar protein, non-collagen nitrogen.

3. Aldolase activity of serum in dystrophic patients was increased many times above the normal value.

\section{REFERENCES}

1. Hoagland, C. L., States of altered metabolism in diseases of muscle. Adv. Enzym., 1946, 6, 193.

2. Lilienthal, J. L., Jr., Zierler, K. L., Folk, B. P., Buka, R., and Riley, M. J., A reference base and system for analysis of muscle constituents. J. Biol. Chem., 1950, 182, 501.

3. Cori, C. F., and Cori, G. T., Polysaccharide phosphorylase. Les Prix Nobel en 1947, 216.

4. Sibley, J. A., and Lehninger, A. L., Determination of aldolase in animal tissues. J. Biol. Chem., 1949, 177, 859.

5. Schapira, G., and Dreyfus, J. C., Recherches sur le Fer musculaire. I. Sur une nouvelle Fraction de Fer non-héminique musculaire. Bull. Soc. chim. biol., 1948, 30, 82.
6. Schapira, G., Dreyfus, J., and Schapira, F., Fer non héminique du muscle en pathologie (myopathies humaines et syndromes experimentaux). First International Congress of Biochemistry, Cambridge, 1949, Abstracts of communications. Abstract No. $177 / 5$, p. 191.

7. Dreyfus, J. C., and Schapira, G., Fer non héminique et protéines musculaires. Bull. Soc. chim. biol., 1949, 31, 442.

8. Dreyfus, J. C., Iron metabolism in muscular diseases. Proceedings of the First and Second Medical Conferences (1951-1952) of the Muscular Dystrophy Association of America, Inc., p. 16.

9. Dreyfus, J. C., and Schapira, G., Syndromes biochimiques musculaires in The Muscle, A study in biology and pathology. Proceedings of the Symposium held at Royaumont, France, 31 August6 September, 1950. L'expansion Scientifique Francaise, Paris, 1952, p. 355.

10. Schapira, G., Dreyfus, J. C., and Schapira, F., Le Fer musculaire au cours des myopathies. Bull Acad. nat. méd., 1948, series 3, vol. 132, Nos. 23 and 24, 435.

11. Lowry, O. H., and Hastings, A. B., Histochemical changes associated with aging. I. Methods and calculations. J. Biol. Chem., 1942, 143, 257.

12. Dounce, A., and Beyer, G. T., A new method for the determination of enzyme aldolase. J. Biol. Chem., 1948, 173, 159.

13. Dounce, A., Barnett, S. R., and Beyer, G. T., Further studies on the kinetics and determination of aldolase. J. Biol. Chem., 1950; 185, 769.

14. Sibley, J. A., and Lehninger, A. L., Aldolase in the serum and tissues of tumor-bearing animals. $\mathrm{J}$. Nat. Cancer Inst., 1949, 9, 303.

15. Neumann, R., and Logan, M., The determination of hydroxyproline. J. Biol. Chem., 1949, 184, 199.

16. Brückmann, G., and Zondek, S. C., Iron, copper and manganese in human organs at various ages. Biochem. J., 1939, 33, 1845.

17. Schapira, G., Dreyfus, J. C., and Schapira, F., L'élévation du taux de l'aldolase sérique test biochimique des myopathies. Semaine d. hôp. Paris, 1953, 29, 1917.

18. Mirski, A., and Wertheimer, E., Muscle action and glycogen phosphorylysis. Biochem. J., 1942, 36, 221.

19. Humoller, F. L., Hatch, D., and McIntyre, A. R., Effect of neurotomy on hexokinase and phosphorylase activities of rat muscle. Am. J. Physiol., 1951, 167, 656.

20. Varga, E., Kostya, K., Szabó, E., Aszódi, L., and Kesztyüs, G., Phosphorylierung in denervierten Muskel. Arch. f. exper. Path. u. Pharmakol., 1950, 210, 214.

21. Fischer, E., Changes in structural proteins and enzymes during muscular atrophy of nervous origin in The Muscle, A study in biology and pathology. Proceedings of the Symposium held at Royaumont, France, 31 August-6 September, 1950. L'expansion Scientifique Francaise, Paris, 1952, p. 275. 